\title{
Differential Interaction of Dantrolene, Glafenine, Nalidixic Acid, and Prazosin with Human Organic Anion Transporters 1 and 3
}

\author{
Birgitta C. Burckhardt, Maja Henjakovic, Yohannes Hagos, and Gerhard Burckhardt \\ Center of Physiology and Pathophysiology, University Medical Center Goettingen, Goettingen, Germany (B.C.B, M.H., Y.H., \\ G.B.); Department I of Internal Medicine, University Medical Center Cologne, Cologne, Germany (M.H.); and PortaCellTec \\ Biosciences GmbH, Goettingen, Germany (Y.H.)
}

Received March 15, 2017; accepted June 14, 2017

\begin{abstract}
In renal proximal tubule cells, the organic anion transporters 1 and 3 (OAT1 and OAT3) in the basolateral membrane and the multidrug resistance-associated protein 4 (MRP4) in the apical membrane share substrates and co-operate in renal drug secretion. We hypothesized that recently identified MRP4 inhibitors dantrolene, glafenine, nalidixic acid, and prazosin also interact with human OAT1 and/or OAT3 stably transfected in human embryonic kidney 293 cells. These four drugs were tested as possible inhibitors of $p-\left[{ }^{3} \mathrm{H}\right]$ aminohippurate $(\mathrm{PAH})$ and $\left[{ }^{14} \mathrm{C}\right]$ glutarate uptake by OAT1, and of $\left[{ }^{3} \mathrm{H}\right]$ estrone-3-sulfate (ES) uptake by OAT3. In addition, we explored whether these drugs decrease the equilibrium distribution of radiolabeled $\mathrm{PAH}$, glutarate, or ES, an approach intended to indirectly suggest drug/substrate exchange through OAT1 and OAT3. With OAT3, a dose-dependent inhibition of $\left[{ }^{3} \mathrm{H}\right] \mathrm{ES}$ uptake and a
\end{abstract}

downward shift in $\left[{ }^{3} \mathrm{H}\right] \mathrm{ES}$ equilibrium were observed, indicating that all four drugs bind to OAT3 and may possibly be translocated. In contrast, the interaction with OAT1 was more complex. With $\left[{ }^{14} \mathrm{C}\right]$ glutarate as substrate, all four drugs inhibited uptake but only glafenine and nalidixic acid shifted glutarate equilibrium. Using $\left[{ }^{3} \mathrm{H}\right] \mathrm{PAH}$ as a substrate of OAT1, nalidixic acid inhibited but dantrolene, glafenine, and prazosin stimulated uptake. Nalidixic acid decreased equilibrium content of $\left[{ }^{3} \mathrm{H}\right] \mathrm{PAH}$, suggesting that it may possibly be exchanged by OAT1. Taken together, OAT1 and OAT3 interact with the MRP4 inhibitors dantrolene, glafenine, nalidixic acid, and prazosin, indicating overlapping specificities. At OAT1, more than one binding site must be assumed to explain substrate and drug-dependent stimulation and inhibition of transport activity.

\section{Introduction}

Efficient renal drug elimination involves active secretion in proximal tubules. Thereby, transporters in the basolateral and luminal (brush-border) membrane co-operate in taking up a drug from blood and delivering it to the primary urine. For anionic, i.e., negatively charged, compounds, the organic anion transporters 1 (OAT1; SLC22A6) and OAT3 (SLC22A8) are the main uptake transporters, functioning physiologically as organic anion $/ \alpha$-ketoglutarate exchangers (reviewed in: VanWert et al., 2010; Pelis and Wright, 2011; Burckhardt, 2012; Morrissey et al., 2013; Nigam et al., 2015), whereas the ATP-driven multidrug resistance-associated proteins MRP2 (ABCC2) and MRP4 (ABCC4) accomplish efflux into the tubule lumen (Masereeuw and Russel, 2010). Co-operation in transcellular drug secretion requires that OATs and MRPs exhibit overlapping specificities for their substrates.

In an ongoing search for specific inhibitors of MRP4, which confers resistance to tumor cells to a variety of antineoplastic agents (for review: Russel et al., 2008; Keppler, 2011; Wen et al., 2015), the FDA-approved drugs dantrolene, glafenine,

This work was supported by institutional funding. https://doi.org/10.1124/jpet.117.241406. nalidixic acid, and prazosin were identified, being even more selective inhibitors than the commonly used leukotriene 4 receptor antagonist MK-571 (Cheung et al., 2015).

Dantrolene, glafenine, nalidixic acid, and prazosin are structurally unrelated and are, at physiologic $\mathrm{pH}$, mainly uncharged (glafenine, prazosin), zwitterionic (dantrolene) or negatively charged (nalidixic acid) (Table 1). In addition, these drugs serve various therapeutic purposes. Dantrolene is the only drug available to treat malignant hyperthermia (Krause et al., 2004, Rosenberg et al., 2015). Glafenine is a nonsteroidal anti-inflammatory agent that was taken off the market (Withdrawal of glafenine, 1992). Nalidixic acid is a quinolone derivative with a wide antibacterial spectrum (Hiraoka et al., 2003; Fabrega et al., 2009), and the antihypertensive prazosin is an $\alpha_{1}$-adrenergic receptor antagonist (Batty et al., 2016; Digne-Malcolm et al., 2016). Owing to their different charges, it was not clear a priori whether these newly identified inhibitors of MRP4 are shared with OAT1 and/or OAT3, although these latter transporters do not exclusively interact with organic anions but also accept some organic cations such as cimetidine (Tahara et al., 2005).

The interaction of a test compound with a transporter can be investigated by several experimental approaches. Most commonly, the potential of test compounds to inhibit the uptake of a reference substrate is determined. Test compound

ABBREVIATIONS: ES, estrone-3-sulfate; HEK, human embryonic kidney; MK-571, 5-(3-(2-(7-chloroquinolin-2-yl)ethenyl)phenyl)-8-dimethylcarbamyl4,6-dithiaoctanoic acid; MRi, mammalian Ringer solution; PAH, p-aminohippurate; OAT, organic anion transporter. 
TABLE 1

Chemical structures and percentage of the ionic forms at $\mathrm{pH} 7.4$ as calculated by MarvinSketch<smiles>O=C1CN(/N=C/c2ccc(-c3ccc([N+](=O)[O-])cc3)o2)C(=O)N1</smiles><smiles>O=C(OCC(O)CO)c1ccccc1Nc1ccnc2cc(Cl)ccc12</smiles><smiles>CCn1cc(C(=O)O)c(=O)c2ccc(C)nc21</smiles>

Prazosin: selective $\alpha_{1}$-adrenergic receptor agonist<smiles>COc1cc2nc(N3CCN(C(=O)c4ccco4)CC3)nc(N)c2cc1OC</smiles>

and radiolabeled reference substrate are offered from the same side ("cis") to cells expressing the transporter under investigation. If an interaction takes place, the test compound cisinhibits substrate uptake. Inhibition, however, does not prove transport of the test compound. To directly demonstrate translocation, the test compound must be available in radio- or fluorescence-labeled form or be detectable by mass spectroscopy. Indirect evidence of translocation is provided by transstimulation experiments in which the labeled substrate is usually offered from the outside and the test agent from the inside of the cell. However, this type of experiment relies on the efficient uptake of test compounds before the addition of the labeled reference substrate. Whether this prior uptake took place is not known in many cases.
Since dantrolene, glafenine, nalidixic acid, and prazosin are not available in radiolabeled form, we employed a technique previously called competitive counter flow (Harper and Wright, 2013). In this setting, cells are equilibrated with their radiolabeled reference substrate. Thereafter, a test compound is added to the medium in the continuous presence of the labeled reference substrate. If the test compound enters the cell via the transporter under investigation, it will force the efflux of radiolabeled reference substrate by exchange (antiport). Thereby, the equilibrium distribution of the reference substrate is distorted, leading to a decrease in its intracellular content. The energy for this downward shift of equilibrium is provided by flux-coupling of drug influx driving substrate efflux. Since OAT1 and OAT3 physiologically operate as antiporters, this technique appeared 
applicable to indirectly test for translocation of dantrolene, glafenine, nalidixic acid, and prazosin by these transporters.

It turned out that all four drugs cis-inhibited OAT3-driven estrone-3-sulfate (ES) uptake and downward shifted the ES equilibrium. With OAT1, dantrolene, glafenine, and prazosin cis-stimulated $p$-aminohippurate $(\mathrm{PAH})$ uptake but cis-inhibited glutarate uptake, suggesting a complex interaction with this transporter. The anionic nalidixic acid cis-inhibited PAH as well as glutarate uptake. A downward shift in equilibrium was observed only with nalidixic acid, suggesting its exchange with intracellular PAH or glutarate through OAT1.

\section{Material and Methods}

Reagents and Chemicals. All chemicals were of analytical grade and purchased from Sigma-Aldrich (Taufkirchen, Germany) or AppliChem (Darmstadt, Germany). Stocks of drugs were prepared in dimethyl sulfoxide, the final concentration of which in the individual experiments did not exceed $0.8 \%$. For dantrolene, glafenine, nalidixic acid, and prazosin, the individual amount of charged or uncharged form was calculated by the free software MarvinSketch 6.3.0 (ChemAxon Ltd., Cambridge, MA) and is displayed in Table 1 . The $\left[{ }^{3} \mathrm{H}\right]$-labeled compounds $p$-aminohippurate and estrone-3-sulfate were from Perkin Elmer (Rodgau, Germany), and $\left[{ }^{14} \mathrm{C}\right]$ glutarate was from Biotrend (Cologne, Germany).

Cell Culture and Transport Experiments. Human embryonic kidney (HEK)293 cells stably transfected with human OAT1 and OAT3 (PortaCellTec Biosciences GmbH, Goettingen, Germany) or vector (pcDNA5) were used. Cell cultures were grown in high-glucose Dulbecco's modified Eagle's medium (Life Technologies GmbH, Darmstadt, Germany), supplemented with $10 \%$ fetal calf serum (European Union approved origin; Life Technologies $\mathrm{GmbH}$ ), $100 \mathrm{units} / \mathrm{ml}$ penicillin and $100 \mu \mathrm{g} / \mathrm{ml}$ streptomycin in an atmosphere of $95 \%$ air and $5 \% \mathrm{CO}_{2}$ at $37^{\circ} \mathrm{C}$. Cells were harvested and plated into 24-well polylysine-coated plastic dishes (Sarstedt, Nuembrecht, Germany) at a density of $2 \times 10^{5}$ cells/well. After 72 hours of incubation, cells were washed twice with $0.5 \mathrm{ml}$ mammalian Ringer solution (MRi) containing in millimolar concentrations (mM): $130 \mathrm{NaCl}, 4 \mathrm{KCl}, 1 \mathrm{CaCl}_{2}, 1 \mathrm{MgSO}_{4}, 1 \mathrm{NaH}_{2} \mathrm{PO}_{4}$, 20 HEPES, and 18 glucose at $\mathrm{pH}$ 7.4. For transport experiments, cells were incubated at $37^{\circ} \mathrm{C}$ in MRi that contained the labeled substrate at the concentration indicated in the respective figure legends. For cisinhibition experiments and determinations of $\mathrm{IC}_{50}$ values, the $\left[{ }^{3} \mathrm{H}\right]$ - or $\left[{ }^{14} \mathrm{C}\right]$-labeled substrate and the potential inhibitor were applied simultaneously in the same well. In equilibrium shift experiments, cells were first allowed to accumulate the labeled substrate to an equilibrium. Afterward, cells were exposed to MRi containing the labeled reference substrate at the same concentration as during the preincubation in the absence or presence of test substrates. In all experiments, uptake was terminated at the time indicated in the figure legends by removal of the medium and followed immediately by three washes with $0.5 \mathrm{ml}$ ice-cold phosphate-buffered saline. Cells were lysed in $0.5 \mathrm{ml} 1 \mathrm{~N} \mathrm{NaOH}$ by gentle shaking for 120 minutes, and the $\left[{ }^{3} \mathrm{H}\right]$ - or $\left[{ }^{14} \mathrm{C}\right]$-content was determined by liquid scintillation counting (Tricarb 2810; Perkin Elmer). Protein quantification was performed according to Bradford (1976).

Data Analysis. Data are presented as means \pm S.D., with calculations of standard deviations made on the basis of the number of separate experiments conducted on cells of three different cell passages. One-way analysis of variance was used to test the effect of possible substrates. $\mathrm{IC}_{50}, \mathrm{EC}_{50}$, and $\mathrm{K}_{\mathrm{m}}$ values were obtained by a fit of dose-response curves by nonlinear regression (SigmaPlot Version 13; Systat Software, San Jose, CA).

\section{Results}

Implications of Dantrolene, Glafenine, Nalidixic Acid, and Prazosin on OAT3. In OAT3-transfected HEK293 cells, dantrolene, glafenine, nalidixic acid, and prazosin inhibited the 5-minute uptake of $10 \mathrm{nM}\left[{ }^{3} \mathrm{H}\right] \mathrm{ES}$ in a concentration-dependent manner with $\mathrm{IC}_{50}$ values of $0.30 \pm 0.03$ (Fig. $\left.1 \mathrm{~A}, \bullet\right), 5.31 \pm 0.74$ $(\bigcirc), 24.87 \pm 1.48(\boldsymbol{\nabla})$, and $29.84 \pm 8.46 \mu \mathrm{M}(\triangle)$, respectively (cisinhibition). Whereas dantrolene was most effective and dantrolene concentrations exceeding $10 \mu \mathrm{M}$ reduced ES uptake close to that observed in pcDNA5-transfected HEK293 cells, inhibition of ES uptake by glafenine, nalidixic acid, and prazosin was partial, including an apparent inhibitor-insensitive part of ES uptake. When $250 \mu \mathrm{M}$ concentration of these drugs was added to cells pre-equilibrated for 60 minutes with $10 \mathrm{nM}$ $\left[{ }^{3} \mathrm{H}\right] \mathrm{ES}$, cellular content of $\left[{ }^{3} \mathrm{H}\right] \mathrm{ES}$ was significantly decreased at 10 minutes despite the continuous presence of $10 \mathrm{nM}\left[{ }^{3} \mathrm{H}\right] \mathrm{ES}$ in the medium (downward shift in equilibrium). The effectiveness of decrease followed the order: dantrolene $>$ glafenine $>$ nalidixic
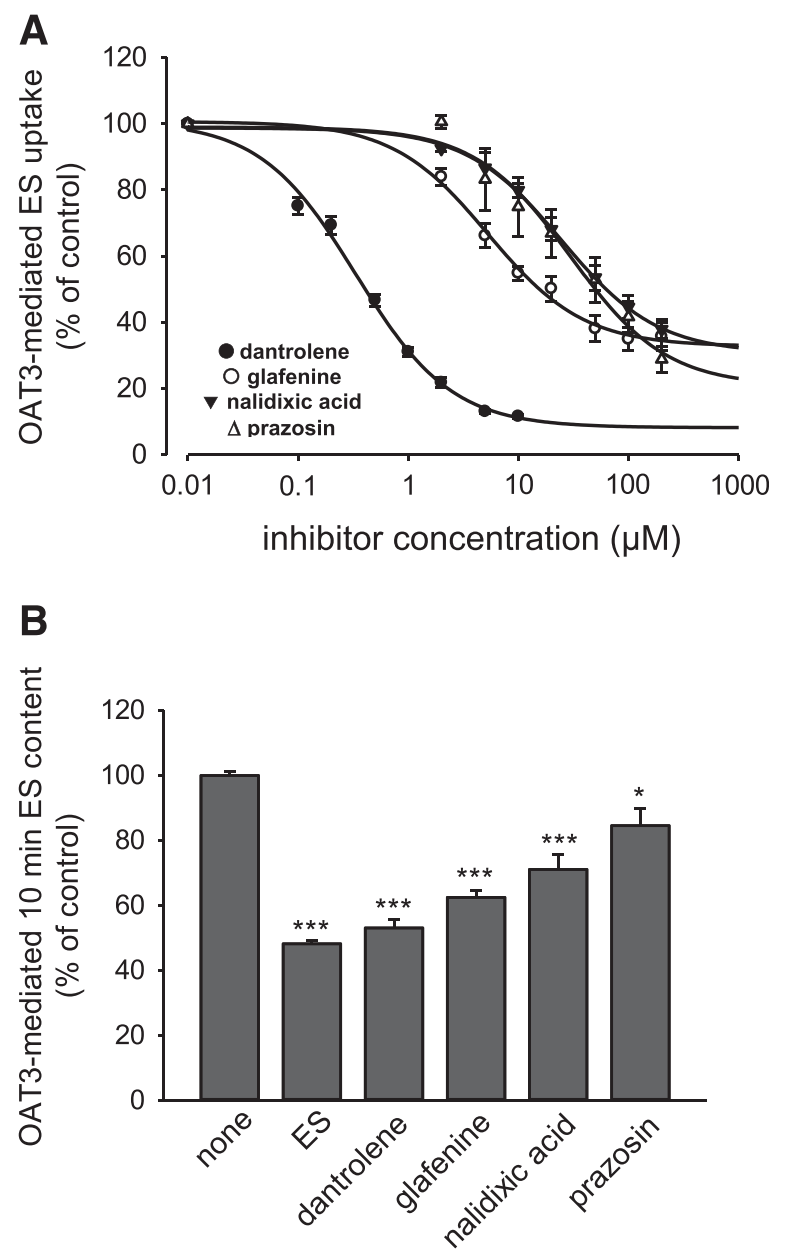

Fig. 1. Impact of dantrolene, glafenine, nalidixic acid, and prazosin on OAT3. (A) Inhibition pattern. OAT3- and pcDNA5-transfected HEK293 cells were incubated for 5 minutes at $37^{\circ} \mathrm{C}$ in MRi containing $10 \mathrm{nM}$ $\left[{ }^{3} \mathrm{H}\right]$ estrone-sulfate (ES) and in addition the following inhibitor concentrations: dantrolene $(\bullet) 0.1,0.2,0.5,1,2,5,10 \mu \mathrm{M}$; glafenine $(\bigcirc)$, nalidixic acid $(\nabla)$, and prazosin $(\Delta) 2,5,10,20,50,100,200 \mu \mathrm{M}$. For better comparison, the OAT3-mediated uptake in the absence of the putative inhibitors was set to $100 \%$. (B) Equilibrium shift assay. OAT3-transfected HEK293 cells were incubated for 60 minutes at $37^{\circ} \mathrm{C}$ in MRi containing $10 \mathrm{nM}\left[{ }^{3} \mathrm{H}\right] \mathrm{ES}$. After a washout, cells were incubated again in MRi containing $10 \mathrm{nM}\left[{ }^{3} \mathrm{H}\right] \mathrm{ES}$ minus or plus unlabeled $250 \mu \mathrm{M}$ of ES, dantrolene, glafenine, nalidixic acid, or prazosin. Ten minutes later, the cellular $\left[{ }^{3} \mathrm{H}\right] \mathrm{ES}$ content was determined. The content in pcDNA-transfected HEK293 cells was subtracted from that measured in OAT1-transfected HEK293 cells. Data are a mean obtained from three cell passages with triplicate determinations each and were normalized. $* P<0.05, * * * P<$ 0.001 with respect to none. 
acid $>$ prazosin (Fig. 1B). Thereby, dantrolene reduced the intracellular $\left[{ }^{3} \mathrm{H}\right] \mathrm{ES}$ content to values similar to those achieved by $250 \mu \mathrm{M}$ unlabeled ES, serving as a control.

Stimulation and Inhibition of OAT1 by Dantrolene, Glafenine, Nalidixic Acid, and Prazosin. In OAT1transfected HEK293 cells, dantrolene, glafenine, nalidixic acid, and prazosin showed, dependent on the reference substrate used, either an increase, a decrease, or no change in their 5 -minute substrate uptake. With $0.25 \mu \mathrm{M}\left[{ }^{3} \mathrm{H}\right] \mathrm{PAH}$ as substrate and dantrolene concentrations of 1-200 $\mu \mathrm{M}$, an increase in the uptake of $\mathrm{PAH}$ was observed that saturated at approximately $250 \%$ of the uptake in the absence of dantrolene (Fig. 2A, ). The concentration for the half-maximal stimulation of $\left[{ }^{3} \mathrm{H}\right] \mathrm{PAH}$ uptake $\left(\mathrm{EC}_{50}\right)$ was calculated to be $1.89 \pm$ $0.25 \mu \mathrm{M}$ dantrolene. In contrast, the 5 -minute uptake of $5 \mu \mathrm{M}$ $\left[{ }^{14} \mathrm{C}\right]$ glutarate was inhibited by dantrolene in a concentrationdependent manner with an $\mathrm{IC}_{50}$ of $78.3 \pm 21.7 \mu \mathrm{M}$ for the dantrolene-sensitive part. Performing similar experiments with glafenine, nalidixic acid, and prazosin revealed the results presented in Fig. 2, B-D, respectively. Glafenine evoked a biphasic response when $\left[{ }^{3} \mathrm{H}\right] \mathrm{PAH}$ was the reference substrate (Fig. 2B, O); low concentrations stimulated and higher concentrations inhibited $\mathrm{PAH}$ uptake. Using $\left[{ }^{14} \mathrm{C}\right]$ glutarate as substrate (Fig. 2B, $\bigcirc$ ), an inhibition with an $\mathrm{IC}_{50}$ of $54.5 \pm 8.9 \mu \mathrm{M}$ was observed. Nalidixic acid resulted in an inhibition of PAH as well as of glutarate uptake with $\mathrm{IC}_{50}$ values of $110.6 \pm 52.2$ (Fig. $2 \mathrm{C}, 0$ ) and $10.8 \pm 1.7 \mu \mathrm{M}$ (Fig. 2C, $\mathrm{)}$, respectively. Prazosin increased $\left[{ }^{3} \mathrm{H}\right] \mathrm{PAH}$ uptake with an $\mathrm{EC}_{50}$ of $4.89 \pm 1.98 \mu \mathrm{M}$ (Fig. 2D, ) with no inhibition of $\left[{ }^{14} \mathrm{C}\right]$ glutarate uptake up to prazosin concentrations of $200 \mu \mathrm{M}$ (Fig. 2D, O).

The experiments shown in Fig. 2 were performed with different substrate concentrations $\left(0.5 \mu \mathrm{M}\left[{ }^{3} \mathrm{H}\right] \mathrm{PAH}, 5 \mu \mathrm{M}\right.$ $\left[{ }^{14} \mathrm{C}\right]$ glutarate) to overcome the low specific radioactivity of $\left[{ }^{14} \mathrm{C}\right]$ glutarate. Decreasing $\left[{ }^{14} \mathrm{C}\right]$ glutarate to $0.5 \mu \mathrm{M}$ did not change the results, i.e., $100 \mu \mathrm{M}$ dantrolene still inhibited glutarate uptake (data not shown). Likewise, increasing $\left[{ }^{3} \mathrm{H}\right] \mathrm{PAH}$ concentration from 0.5 to $10 \mu \mathrm{M}$ did not abolish the stimulating effect of $100 \mu \mathrm{M}$ dantrolene on PAH uptake (data not shown). Thus, the differential effects of dantrolene and, by inference, of the other drugs on $\mathrm{PAH}$ and glutarate uptake are not the result of different substrate concentrations but indicate a substrate-dependent effect.

Shift in Equilibrium Using Glutarate as a Reference Substrate of OAT1. After a 5-minute incubation time, $\left[{ }^{14} \mathrm{C}\right]$ glutarate uptake into OAT1-transfected cells tended to saturate with increasing glutarate concentrations (Fig. 3A, O). In pcDNA5-tranfected cells, $\left[{ }^{14} \mathrm{C}\right]$ glutarate uptake rose linearly with glutarate concentration $(\bigcirc)$. OAT1-dependent uptake was obtained by subtracting $\left[{ }^{14} \mathrm{C}\right]$ glutarate in pcDNA5- from that in OAT1-transfected cells ( $)$. From the OAT1-mediated uptake, a $\mathrm{K}_{\mathrm{m}}$ of $65.2 \pm 7.6 \mu \mathrm{M}$ was calculated for glutarate on the basis of Michaelis-Menten kinetics. As an internal control, a $\mathrm{K}_{\mathrm{m}}$ for the uptake of $\left[{ }^{3} \mathrm{H}\right] \mathrm{PAH}$ was determined on the same batch of cells. After correction for non-OAT1-mediated PAH uptake, a $\mathrm{K}_{\mathrm{m}}$ of $57.0 \pm 3.4 \mu \mathrm{M}$ was found (data not shown). Hence, the $\mathrm{K}_{\mathrm{m}}$ values for glutarate and PAH turned out to be similar in our cells.

Uptake of $5 \mu \mathrm{M}\left[{ }^{14} \mathrm{C}\right]$ glutarate reached an equilibrium at incubation times exceeding 30 minutes (Fig. 3B, O). Uptake of $\left[{ }^{14} \mathrm{C}\right]$ glutarate into pcDNA5-transfected HEK293 cells increased linearly (Fig. 3B, $\bigcirc$ ) but was at all times much smaller than uptake into OAT1-transfected cells. After a 60-minute equilibration in MRi containing $5 \mu \mathrm{M}\left[{ }^{14} \mathrm{C}\right]$ glutarate, OAT1and pcDNA5-transfected HEK293 cells were transferred in
A
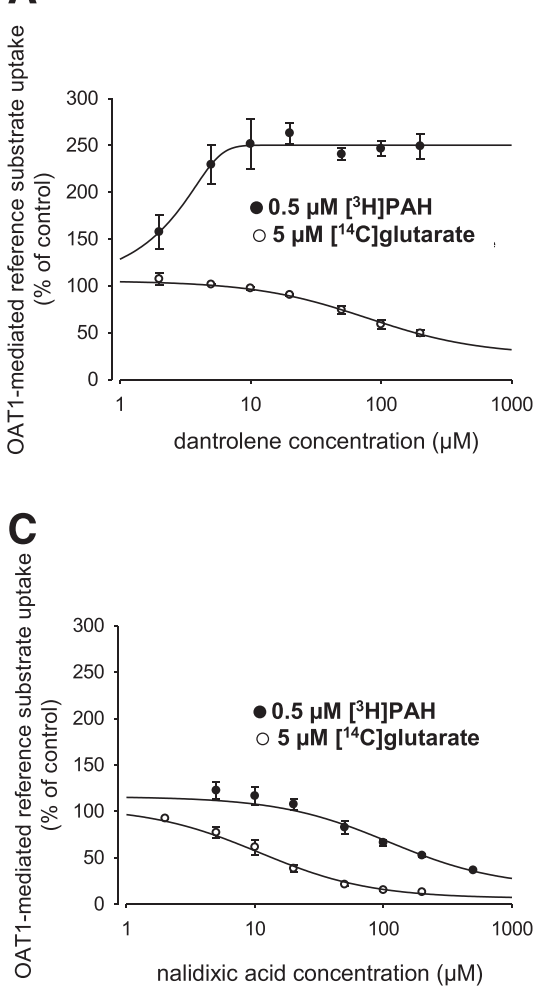
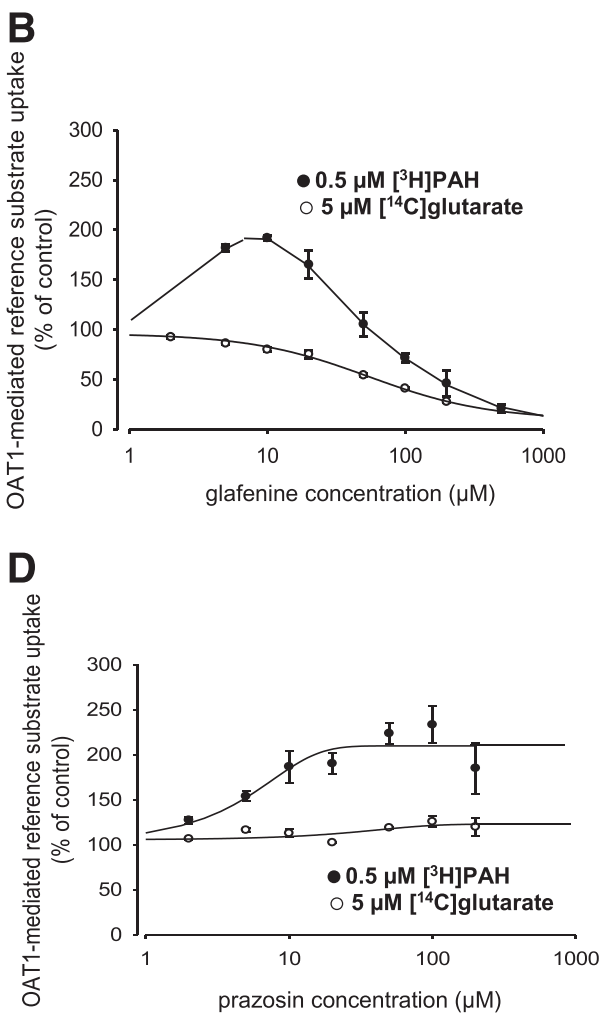

Fig. 2. Differential effects of drugs on OAT1-mediated PAH and glutarate transport. The 5-minute uptakes of $0.25 \mu \mathrm{M}\left[{ }^{3} \mathrm{H}\right] \mathrm{PAH}(\bullet)$ and of $5 \mu \mathrm{M}\left[{ }^{14} \mathrm{C}\right]$ glutarate $(\mathrm{O})$ in response to increasing concentrations of (A) dantrolene, (B) glafenine, (C) nalidixic acid, and (D) prazosin were determined. Uptakes of glutarate and PAH in pcDNA5transfected HEK293 cells were subtracted from the uptakes in OAT1-transfected HEK293 cells (OAT1mediated reference substrate uptake). Data are means obtained from three consecutive cell passages, each run in triplicate. 

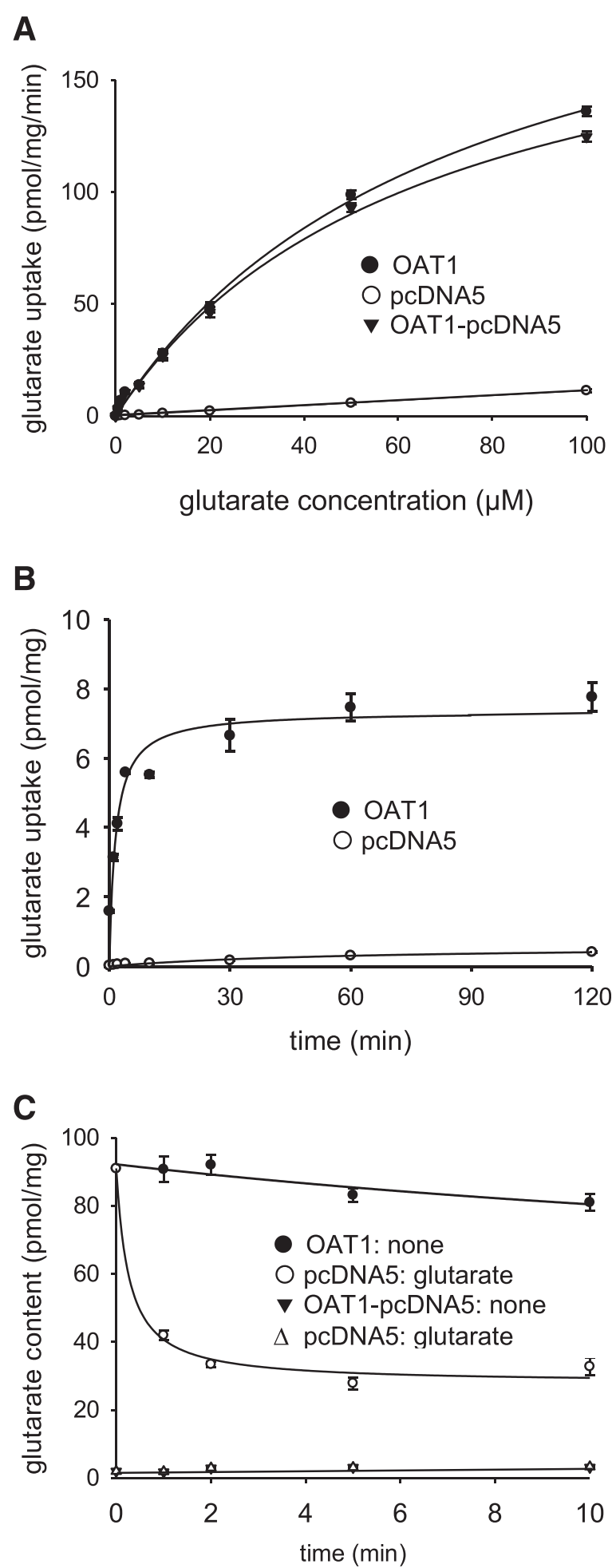

Fig. 3. Evaluation of experimental conditions for equilibrium shifts, using glutarate as a reference substrate for OAT1. (A) Determination of a Michaelis-Menten $\left(\mathrm{K}_{\mathrm{m}}\right)$ constant for glutarate. In OAT1- $(\bullet)$ and pcDNA5transfected HEK293 cells $(\bigcirc)$, the 5-minute uptake of glutarate was measured using the following glutarate concentrations (in $\mu \mathrm{M}$ ): $0.5,1,2,5$, $10,20,50,100$. The concentrations $10-100 \mu \mathrm{M}$ were applied as a mixture of $5 \mu \mathrm{M}\left[{ }^{14} \mathrm{C}\right]$ glutarate supplemented with $5,15,45$, or $95 \mu \mathrm{M}$ unlabeled glutarate, respectively. Concentrations of $0.5,1,2$, and $5 \mu \mathrm{M}$ glutarate contained only $\left[{ }^{14} \mathrm{C}\right]$ glutarate. The inverted solid triangle $(\mathbf{\nabla})$ represents the OAT1-mediated part of glutarate uptake from which the $\mathrm{K}_{\mathrm{m}}$ was calculated. (B) Time course of glutarate uptake. The uptake of $5 \mu \mathrm{M}\left[{ }^{14} \mathrm{C}\right]$ glutarate was followed over 120 minutes in OAT1- (๑) and pcDNA5-transfected HEK293 cells $(\mathrm{O})$. (C) Time course of $\left[{ }^{14} \mathrm{C}\right]$ glutarate equilibrium shift of OAT1- and
MRi containing again $5 \mu \mathrm{M}\left[{ }^{14} \mathrm{C}\right]$ glutarate but now in the absence and presence of $250 \mu \mathrm{M}$ unlabeled glutarate. A timedependent decrease in cellular $\left[{ }^{14} \mathrm{C}\right]$ glutarate content was detected upon application of $250 \mu \mathrm{M}$ unlabeled glutarate in MRi (Fig. 3C, O), which stabilized at times beyond 2 minutes. The $\left[{ }^{14} \mathrm{C}\right]$ glutarate content at 10 minutes was $35.9 \pm 2.7 \%$ of the $\left[{ }^{14} \mathrm{C}\right]$ glutarate content in the absence of $250 \mu \mathrm{M}$ glutarate. The sole application of $\mathrm{MRi}$ containing $5 \mu \mathrm{M}\left[{ }^{14} \mathrm{C}\right]$ glutarate decreased the $\left[{ }^{14} \mathrm{C}\right]$ glutarate content by less than $20 \%$ within 10 minutes (Fig. 3C, $\bullet$ ). The substantial decrease in cellular $\left[{ }^{14} \mathrm{C}\right]$ glutarate content in the continuous presence of $\left[{ }^{14} \mathrm{C}\right]$ glutaratein MRi plus external unlabeled glutarate indicates a downward shift in equilibrium most probably resulting from an exchange of extracellular unlabeled glutarate against intracellular $\left[{ }^{14} \mathrm{C}\right]$ glutarate through OAT1.

Equilibrium Shifts Induced by Substrates and Drugs Using Glutarate as a Reference Substrate of OAT1. In these experiments, cellular $\left[{ }^{14} \mathrm{C}\right]$ glutarate was measured in the absence and presence of test substances at 10 minutes. Addition of the OAT1 substrates $250 \mu \mathrm{M}$ PAH or $250 \mu \mathrm{M}$ glutarate decreased the 10-minute glutarate content in OAT1-transfected HEK293 cells to $35.8 \pm 11.0 \%$ or $34.8 \pm 4.4 \%$ of the value in the absence of glutarate or PAH (Fig. 4A, gray bars). Probenecid and succinate (both at $250 \mu \mathrm{M}$ ) also reduced the 10-minute glutarate content. In pcDNA5-transfected cells, $\left[{ }^{14} \mathrm{C}\right]$ glutarate uptake was rather stimulated by extracellular glutarate, $\mathrm{PAH}$, succinate, and probenecid but it remained negligible with respect to uptake into OAT1-transfected cells. The reason for this apparent stimulation in pcDNA5-transfected cells is unknown.

Applied to OAT1-expressing cells after preincubation with $\left[{ }^{14} \mathrm{C}\right]$ glutarate, $250 \mu \mathrm{M}$ dantrolene slightly decreased 10 -minute glutarate content, and $250 \mu \mathrm{M}$ prazosin tended to increase it, but both effects did not reach statistical significance (Fig. 4B, gray bars). In contrast, nalidixic acid and glafenine both reduced 10-minute glutarate content by $74.3 \pm 1.0 \%$ and $43.1 \pm 16.9 \%$, respectively. Again, in pcDNA5-transfected HEK293 cells, the drugs rather increased the 10-minute glutarate content (Fig. $4 \mathrm{~B}$, black bars). Correcting $\left[{ }^{14} \mathrm{C}\right]$ glutarate content in OAT1expressing cells by that in pcDNA5-cells revealed significant equilibrium shifts induced by glafenine and nalidixic acid but not by dantrolene and prazosin (Fig. 4C).

Shifts in Equilibrium with PAH as a Reference Substrate for OAT1. In OAT1-transfected HEK293 cells, timedependent uptake of $\left[{ }^{3} \mathrm{H}\right] \mathrm{PAH}$ already leveled off at 5 minutes (Fig. 5A, ๑), indicating a fast equilibration. In pcDNA5transfected HEK293 cells, the uptake $0.25 \mu \mathrm{M}\left[{ }^{3} \mathrm{H}\right] \mathrm{PAH}$ increased less steeply and tended to level off at incubation times beyond 30 minutes $(\bigcirc)$. OAT1-mediated PAH uptake, i.e., uptake into OAT1- minus uptake into pcDNA5-transfected cells, showed a maximum at about 3 minutes of incubation (Fig. 5A, inset).

For the further experiments, 10 minutes of pre-equilibration with $\left[{ }^{3} \mathrm{H}\right] \mathrm{PAH}$ were used. After this time, cells were transferred to MRi containing $0.25 \mu \mathrm{M}\left[{ }^{3} \mathrm{H}\right] \mathrm{PAH}$ in the absence and presence of $250 \mu \mathrm{M}$ unlabeled $\mathrm{PAH}$, and changes in the content

pcDNA5-transfected HEK293 cells in the absence (OAT1: $\bullet$; pcDNA5: $\mathbf{\nabla}$ ) and presence of $250 \mu \mathrm{M}$ glutarate (OAT1: $\bigcirc$; pcDNA5: $\Delta$ ). After a 60 -minute equilibration in $5 \mu \mathrm{M}\left[{ }^{14} \mathrm{C}\right]$ glutarate, cells were transferred to MRi containing again $5 \mu \mathrm{M}\left[{ }^{14} \mathrm{C}\right]$ glutarate without or with $250 \mu \mathrm{M}$ unlabeled glutarate, and the decay in cellular $\left[{ }^{14} \mathrm{C}\right]$ glutarate content was followed with time. Data shown in (A), (B), and (C) are a mean obtained on three consecutive cell passages, each run in triplicate. 


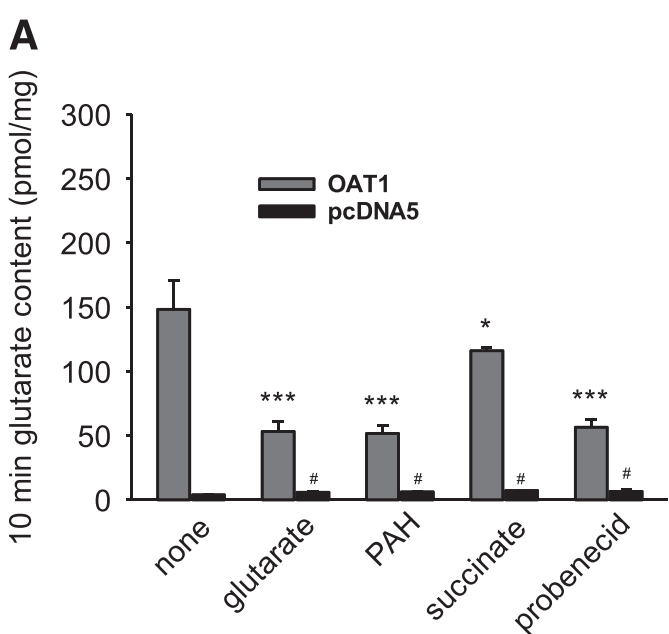

B
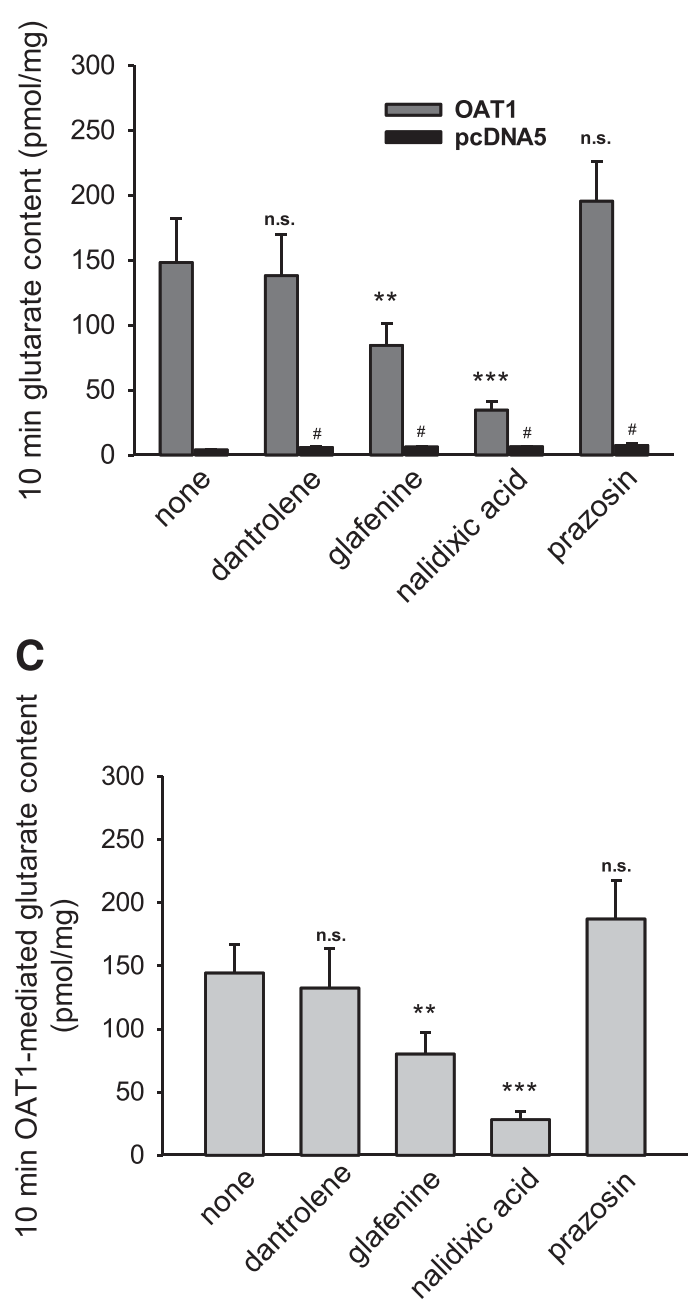

Fig. 4. Equilibrium shifts performed with established OAT1 substrates and drugs. OAT1- and pcDNA5-transfected HEK293 cells were incubated for 60 minutes at $37^{\circ} \mathrm{C}$ in MRi containing $5 \mu \mathrm{M}\left[{ }^{14} \mathrm{C}\right]$ glutarate. Afterward, cells were incubated for 10 minutes in $5 \mu \mathrm{M}\left[{ }^{14} \mathrm{C}\right]$ glutarate minus or plus $250 \mu \mathrm{M}$ (A) glutarate, $\mathrm{PAH}$, succinate, and probenecid or (B) dantrolene, glafenine, nalidixic acid, or prazosin. (C) The OAT1-mediated 10-minute glutarate content was achieved by subtraction of the 10-minute glutarate content measured in pcDNA5- from that in OAT1-transfected HEK293 cells. Data presented in (A), (B), and (C) are means obtained from three consecutive cell passages, each run in triplicate. Statistically significant differences from OAT1-transfected HEK293 cells not exposed to test compounds (none); of $\left[{ }^{3} \mathrm{H}\right] \mathrm{PAH}$ were monitored as a function of time (Fig. 5B). The PAH content in pcDNA5-transfected HEK293 cells increased slightly with time, independent of whether unlabeled PAH was present in MRi or not (Fig. 5B, $\nabla, \Delta$ ). In OAT1-transfected HEK293 cells, application of $0.25 \mu \mathrm{M}\left[{ }^{3} \mathrm{H}\right] \mathrm{PAH}$ in MRi evoked only small changes in PAH content with time (Fig. 5B, O). However, when $250 \mu \mathrm{M}$ unlabeled $\mathrm{PAH}$ was added, the cellular $\left[{ }^{3} \mathrm{H}\right] \mathrm{PAH}$ content decreased, showed a minimum at 2 minutes, and increased slightly with time afterward (Fig. 5B, $\bigcirc$ ), revealing a downward shift in equilibrium most probably attributable to $\mathrm{PAH} /\left[{ }^{3} \mathrm{H}\right] \mathrm{PAH}$ exchange through OAT1.

Equilibrium Shifts Induced by Substrates and Drugs Using PAH as a Reference Substrate for OAT1. Measuring the 2-minute PAH content in the absence and presence of extracellular $250 \mu \mathrm{M}$ PAH, glutarate, or succinate revealed a decrease in $\left[{ }^{3} \mathrm{H}\right] \mathrm{PAH}$ content by $\mathrm{PAH}$ and glutarate but not by succinate (Fig. 6A, gray bars). In pcDNA5-transfected HEK293 cells (Fig. 6A, black bars), the $\left[{ }^{3} \mathrm{H}\right] \mathrm{PAH}$ content increased rather than decreased by application of $\mathrm{PAH}$, glutarate, and succinate. Dantrolene and prazosin $(250 \mu \mathrm{M})$ increased the 2-minute $\left[{ }^{3} \mathrm{H}\right] \mathrm{PAH}$ content compared with none, but glafenine and nalidixic acid did not significantly affect the 2-minute $\mathrm{PAH}$ content (Fig. 6B). In pcDNA5-transfected HEK293 cells, the 2-minute $\mathrm{PAH}$ content was significantly higher in the presence of the drugs than in their absence (Fig. 6B, black bars). Calculation of the 2-minute OAT1-dependent $\left[{ }^{3} \mathrm{H}\right] \mathrm{PAH}$ content, i.e., uptake into OAT1- minus uptake into pcDNA5-transfected cells, revealed a significant decrease by nalidixic acid but not by dantrolene, glafenine, and prazosin (Fig. 6C).

\section{Discussion}

Secretion of organic anions in renal proximal tubules involves uptake across the basolateral membrane and release across the luminal membrane. Uptake is mainly accomplished by two transporters of wide and overlapping substrate specificities, organic anion transporters 1 and 3 (OAT1 and OAT3; gene names SLC22A6 and SLC22A8; reviewed in VanWert et al., 2010; Pelis and Wright, 2011; Burckhardt, 2012; Morrissey et al., 2013; Nigam et al., 2015). These OATs take up organic anions from the blood in exchange against intracellular $\alpha$-ketoglutarate. Since a high intracellular $\alpha$-ketoglutarate concentration is maintained by metabolism and by sodium-driven uptake across luminal and basolateral membranes (Dantzler, 2002), organic anion transport across the basolateral membrane is continuously poised in the uptake direction. Multidrug resistance-associated protein 4 (MRP4; gene name ABCC4) is an ATP-driven export pump that is, among other transporters, involved in the release of organic anions into the primary urine (reviewed in Russel et al., 2008; Keppler, 2011; Wen et al., 2015). ATP hydrolysis provides the driving force for organic anion efflux across the luminal membrane.

When OAT1/3 in the basolateral membrane and MRP4 in the luminal membrane are to co-operate efficiently in proximal tubular anion secretion, it is mandatory that their spectrum of transported substrates overlaps broadly. Hence,

$* * * P<0.001, * * P<0.01, * P<0.05$; n.s., not significant. Statistically significant differences compared to pcDNA5-transfected HEK293 cells (none); ${ }^{\#} P<0.05$. 

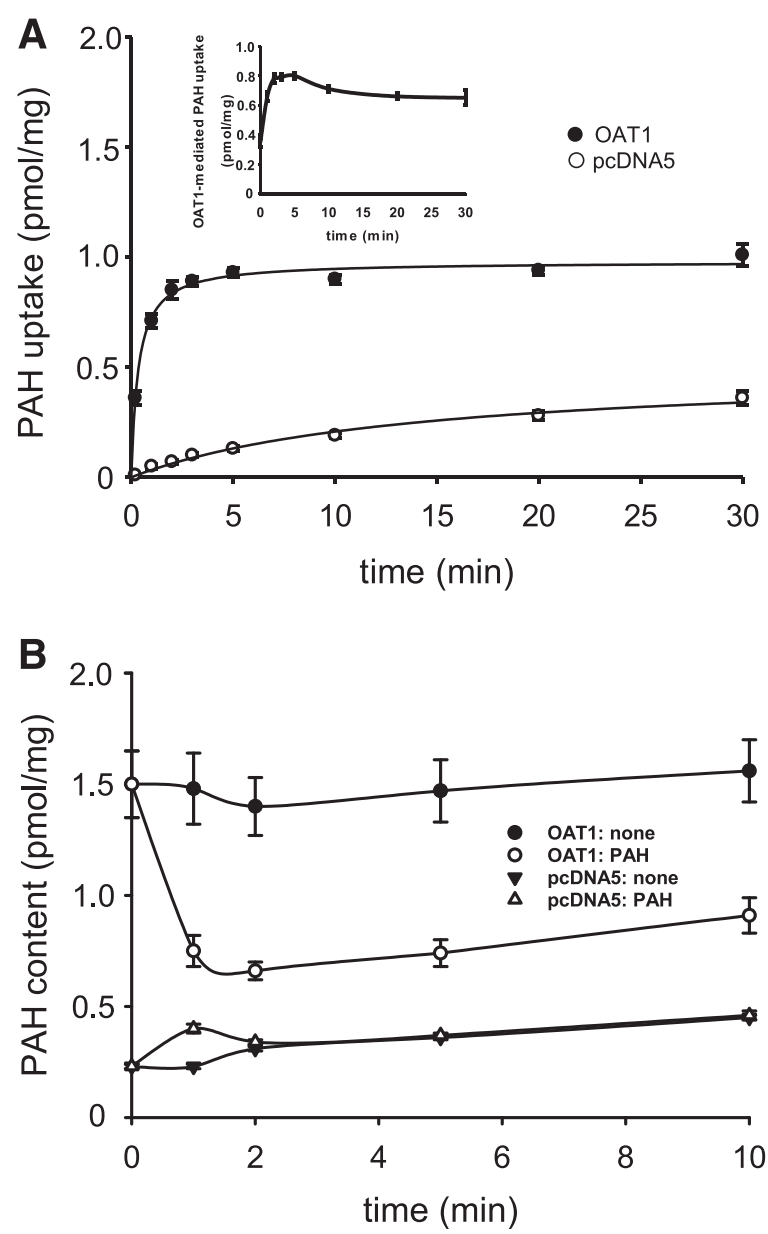

Fig. 5. Evaluation of experimental conditions for equilibrium shifts using PAH as a reference substrate for OAT1. (A) Time course of PAH uptake. The uptake of $0.25 \mu \mathrm{M}\left[{ }^{3} \mathrm{H}\right] \mathrm{PAH}$ uptake was followed over 30 minutes in OAT1- $(-)$ and pcDNA5-transfected HEK293 cells $(O)$. The inset shows the OAT1-mediated PAH uptake. (B) Time course of intracellular PAH content of OAT1- and pcDNA5-transfected HEK293 cells in the absence (OAT1: - pcDNA5: $\mathbf{\nabla}$ ) and presence of $250 \mu \mathrm{M}$ PAH (OAT1: $\bigcirc$; pcDNA5: $\Delta$ ). After 10-minute equilibration in $0.25 \mu \mathrm{M}\left[{ }^{3} \mathrm{H}\right] \mathrm{PAH}$, cells were transferred to MRi containing again $0.25 \mu \mathrm{M}\left[{ }^{3} \mathrm{H}\right] \mathrm{PAH}$ without and with $250 \mu \mathrm{M}$ unlabeled $\mathrm{PAH}$ and the change in cellular $\left[{ }^{3} \mathrm{H}\right] \mathrm{PAH}$ content was followed with time. Data shown in (A) and (B) are means obtained on three consecutive cell passages, each run in triplicate.

we reasoned that the recently detected MRP4 inhibitors dantrolene, glafenine, nalidixic acid, and prazosin (Cheung et al., 2015) could interact with OAT1 and OAT3 as well. To demonstrate interaction we used two types of experiments: cisinhibition studies and equilibrium shift assays on HEK293 cells stably expressing human OAT1 or OAT3. Given the unavailability of labeled drugs, the latter type of experiment was performed to obtain an indirect indication, though not a proof, of drug translocation by OAT1 and OAT3. If an extracellularly added drug decreases the amount of intracellularly labeled reference substrate in the continuous presence of extracellularly labeled reference substrate, i.e., shifts the equilibrium to lower values, an exchange (antiport) of drug against reference substrate may have taken place at the transporter under investigation.

With OAT3, straightforward results were obtained using dantrolene, glafenine, nalidixic acid, and prazosin as test substances. In cis-inhibition experiments, all compounds inhibited ES uptake dose dependently, indicating a hitherto unknown interaction with human OAT3. Dantrolene, with an $\mathrm{IC}_{50}$ of
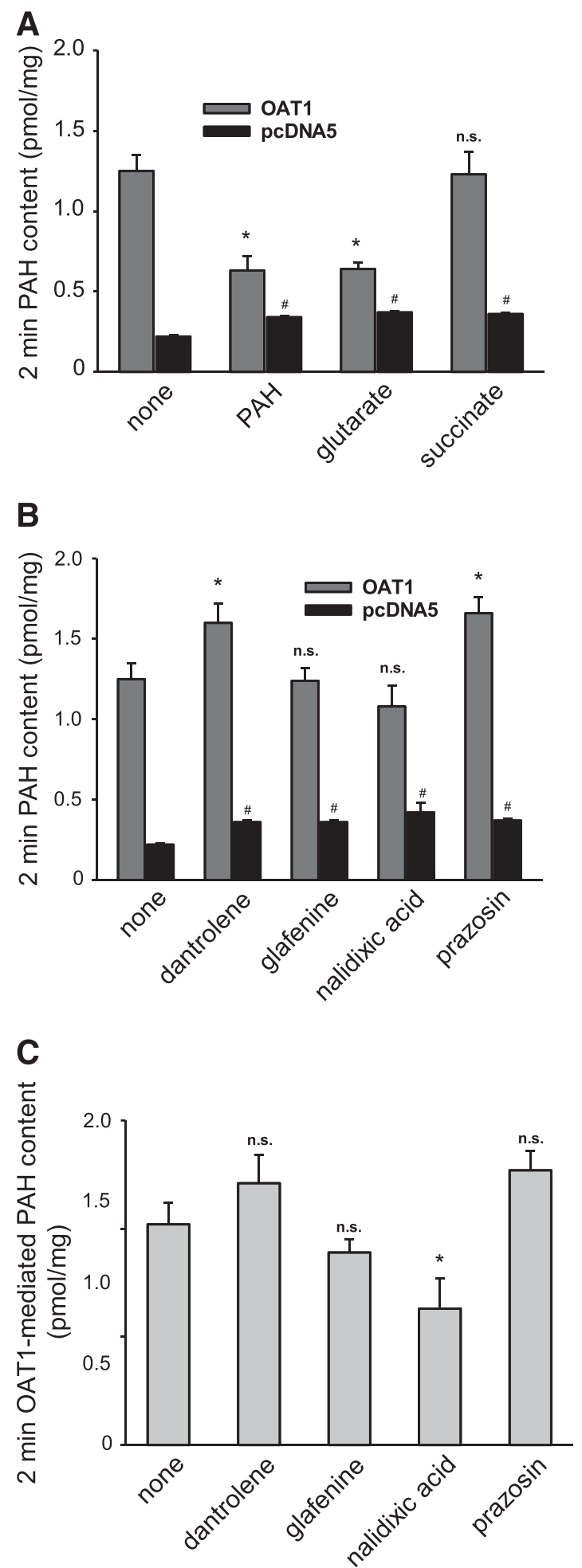

Fig. 6. Equilibrium shifts induced by established OAT1 substrates and drugs. OAT1- and pcDNA5-transfected HEK293 cells were incubated for 10 minutes at $37^{\circ} \mathrm{C}$ in MRi containing $0.25 \mu \mathrm{M}\left[{ }^{3} \mathrm{H}\right] \mathrm{PAH}$. Afterward, cells were incubated for 2 minutes in $0.25 \mu \mathrm{M}\left[{ }^{3} \mathrm{H}\right] \mathrm{PAH}$ minus or plus $250 \mu \mathrm{M}$ (A) PAH, glutarate, and succinate or (B) dantrolene, glafenine, nalidixic acid, or prazosin. (C) Subtraction of the 2-minute PAH content observed in pcDNA5- from that observed in OAT1-transfected HEK293 cells revealed the OAT1-mediated PAH content. Data presented in (A), (B), and (C) are a mean obtained on three consecutive cell passages, each run in triplicate. Statistically significant differences from OAT1-transfected HEK293 cells not exposed to test compounds (none) ${ }^{* * *} P<0.001$, $* P<0.05$, n.s.: not significant. Statistically significant differences from pcDNA5-transfected HEK293 cells (none); ${ }^{\#} P<0.05$. 
TABLE 2

Comparison of the interaction of dantrolene, glafenine, nalidixic acid, and prazosin with OAT1, OAT3, and MRP4

Shown are maximum plasma concentrations, $\mathrm{C}_{\max }$, in $\mu \mathrm{g} / \mathrm{ml}$ as reported in the literature and recalculated in $\mu \mathrm{M}$, and the $\mathrm{IC}_{50}$ (inhibition), or $\mathrm{EC}_{50}$ (stimulation; values labeled with *) values determined in this study for OAT1 with PAH or glutarate as substrates and OAT3 with estrone-3sulfate as substrate. The last two columns show the concentration of compounds that inhibited apoptosis induced by 6-mercaptopurine or ISN-38 in MRP4-transfected HEK293 cells.

\begin{tabular}{|c|c|c|c|c|c|c|c|c|}
\hline \multirow[b]{2}{*}{ Compound } & \multirow[b]{2}{*}{ MW } & \multirow{2}{*}{\multicolumn{2}{|c|}{$\mathrm{C}_{\max }$}} & \multicolumn{3}{|c|}{$\mathrm{IC}_{50} / \mathrm{EC}_{50} *$} & \multicolumn{2}{|c|}{$\mathrm{IC}_{50}$} \\
\hline & & & & OAT1 & OAT1 & OAT3 & $\mathrm{MRP}^{a}{ }^{a}$ & $\mathrm{MRP}^{a}$ \\
\hline & $\mathrm{g} / \mathrm{mol}$ & $\mu g / m l$ & $\mu M$ & $\mu M$ & $\mu M$ & $\mu M$ & $\mu M$ & $\mu M$ \\
\hline Dantrolene & 314.25 & $9.0 \pm 4.6^{b}$ & 28.6 & $1.89 \pm 0.25^{*}$ & $78.3 \pm 21.7$ & $0.30 \pm 0.03$ & 5.29 & 4.2 \\
\hline Glafenine & 372.80 & $0.7-2.2^{c}$ & $1.8-5.9$ & Biphasic & $54.5 \pm 8.9$ & $5.31 \pm 0.74$ & 12.3 & 5.7 \\
\hline Nalidixic acid & 232.24 & $20-40^{d}$ & $86.1-172.3$ & $110.6 \pm 52.2$ & $10.8 \pm 1.7$ & $24.87 \pm 1.48$ & 9.2 & 13.3 \\
\hline Prazosin & 383.40 & $\begin{array}{r}0.017^{e} \\
<0.150^{f}\end{array}$ & $0.04 ; 0.39$ & $4.89 \pm 1.98^{*}$ & $>>200$ & $29.84 \pm 8.46$ & 11.0 & 7.2 \\
\hline
\end{tabular}

\footnotetext{
${ }^{a}$ Cheung et al., 2015.

${ }^{b}$ Ryanodex (data sheet).

${ }^{c}$ Vermerie et al., 1992.

${ }^{d}$ Nalidixic acid (Drugs.com)

${ }^{e}$ Guelen et al., 1990

fJaillon, 1980.
}

$0.3 \mu \mathrm{M}$, turned out to be a very potent inhibitor, followed by glafenine $(5.3 \mu \mathrm{M})$, nalidixic acid $(24.9 \mu \mathrm{M})$, and prazosin $(29.8 \mu \mathrm{M})$. For comparison, MK571 inhibited OAT3- and MRP4mediated substrate uptake with an $\mathrm{IC}_{50}$ of $1.6 \mu \mathrm{M}$ (Henjakovic et al., 2015) and $10 \mu \mathrm{M}$ (Reid et al., 2003), respectively. It appears that the net charge of the compounds does not play an important role in OAT3 selectivity for these drugs. At physiologic $\mathrm{pH}$, only $12.9 \%$ of dantrolene is net negatively charged, and $96.6 \%$ of nalidixic acid is present in the anionic form; yet dantrolene was a more potent inhibitor than nalidixic acid. Prazosin and nalidixic acid were equipotent inhibitors despite the fact that prazosin is partially cationic $(41.1 \%)$ and nalidixic acid is nearly completely anionic. The previously described interaction of OAT3 with the cationic $\mathrm{H}_{2}$ receptor antagonist cimetidine is in line with the assumption that this transporter is able to interact with organic anions, zwitterions, and cations (Tahara et al., 2005). In equilibrium shift assays, unlabeled ES was most and prazosin least effective in decreasing the cellular $\left[{ }^{3} \mathrm{H}\right] \mathrm{ES}$ content, suggesting that extracellular ES and possibly also the drugs exchanged for intracellular $\left[{ }^{3} \mathrm{H}\right] \mathrm{ES}$ via OAT3. Alternatively, the drugs only inhibited OAT3 and left an as yet undefined $\left[{ }^{3} \mathrm{H}\right] \mathrm{ES}$ efflux transporter unchanged.

Testing the drugs on OAT1 revealed results that are more difficult to interpret. Using $\left[{ }^{14} \mathrm{C}\right]$ glutarate as a substrate, nalidixic acid $\left(\mathrm{IC}_{50} 10.8 \mu \mathrm{M}\right)$, glafenine $(54.5 \mu \mathrm{M})$, and dantrolene $(78.3 \mu \mathrm{M})$ inhibited OAT1 activity. Prazosin had no effect. The rank order of inhibition is distinct from that on OAT3 (see above) and the $\mathrm{IC}_{50}$ values tended to be higher (see Table 2 ). When $\left[{ }^{3} \mathrm{H}\right] \mathrm{PAH}$ was used as a substrate, dantrolene and prazosin cis-stimulated uptake, and glafenine showed a biphasic effect (cis-stimulation followed by cis-inhibition at higher concentrations). Nalidixic acid inhibited $\left[{ }^{3} \mathrm{H}\right] \mathrm{PAH}$ uptake with an $\mathrm{IC}_{50}$ of $110 \mu \mathrm{M}$.

Stimulation of $\left[{ }^{3} \mathrm{H}\right] \mathrm{PAH}$ uptake by dantrolene occurred with an $\mathrm{EC}_{50}$ of $1.89 \mu \mathrm{M}$ and a maximum stimulation was reached at $10 \mu \mathrm{M}$. Thereby, the $\mathrm{EC}_{50}$ was considerably lower than the $\mathrm{IC}_{50}$ for the inhibition of $\left[{ }^{14} \mathrm{C}\right]$ glutarate uptake, suggesting two independent actions of dantrolene on OAT1. Prazosin stimulated $\left[{ }^{3} \mathrm{H}\right] \mathrm{PAH}$ uptake with an $\mathrm{EC}_{50}$ of $4.9 \mu \mathrm{M}$ and did not inhibit $\left[{ }^{14} \mathrm{C}\right]$ glutarate uptake at all, again indicating that stimulation of $\left[{ }^{3} \mathrm{H}\right] \mathrm{PAH}$ uptake and inhibition of $\left[{ }^{14} \mathrm{C}\right]$ glutarate uptake imply different sites at OAT1. In our OAT1-transfected HEK293 cells, the $\mathrm{K}_{\mathrm{m}}$ for PAH $(57 \mu \mathrm{M})$ and glutarate $(65.2 \mu \mathrm{M})$ were undistinguishable. Hence, the differential effect cannot be the result of different affinities of OAT1 for PAH and glutarate but indicates a reference substrate-specific effect.

Substrate-dependent cis-stimulation and cis-inhibition was recently reported for OATP1B3-expressing CHO cells: The green tea constituent epigallocatechin gallate (EGCG) dose dependently stimulated $\left[{ }^{3} \mathrm{H}\right] \mathrm{ES}$ uptake, inhibited Fluo-3 uptake, and left estrogen-17 $\beta$ glucuronide uptake unchanged (Roth et al., 2011). The authors reasoned that this behavior is indicative of multiple binding sites and/or different transport modes of OATP1B3. Likewise, we assume also for OAT1 multiple binding sites with different transport modes and kinetics. This may be a hallmark of polyspecific transporters that accept a wide variety of compounds for transport (see also results on the organic cation transporters; Egenberger et al., 2012; Belzer et al., 2013; Ingraham et al., 2014; Hotchkiss et al., 2015). Possibly, OAT1 has at least two binding sites: one for translocation of $\mathrm{PAH}$ and another one for allosteric cisstimulation by dantrolene, glafenine, or prazosin. Nalidixic acid and, at higher concentrations, glafenine may displace $\mathrm{PAH}$ from the transport site, leading to a cis-inhibition. In case of glutarate transport, all drugs were inhibitory. As a divalent anion with spatially separated charges, glutarate may bind to the "PAH transport site" and to an additional transport site that may partially overlap with the allosteric binding site for drugs. In consequence, the drugs would displace glutarate and thus cis-inhibit transport.

The equilibrium content of $\left[{ }^{14} \mathrm{C}\right]$ glutarate in OAT1-expressing cells was decreased by $\mathrm{PAH} \sim$ glutarate $>>$ succinate. This sequence fits well with the affinity of OAT1 toward these translocated substrates (Kaufhold et al., 2011). In equilibrium shift assays, glafenine and nalidixic acid decreased intracellular $\left[{ }^{14} \mathrm{C}\right]$ glutarate content, whereas only nalidixic acid also reduced intracellular $\left[{ }^{3} \mathrm{H}\right] \mathrm{PAH}$ content. Dantrolene and prazosin were without effect. It is, therefore, possible that nalidixic acid exchanges with intracellular labeled substrates through OAT1. Alternatively, nalidixic acid may inhibit influx without disturbing efflux of $\left[{ }^{3} \mathrm{H}\right] \mathrm{PAH}$ or $\left[{ }^{14} \mathrm{C}\right]$ glutarate through an undefined transporter. Whereas PAH may well be pumped back out by MRP4 (Smeets et al., 2004) that is endogenously expressed in HEK cells (Cheung et al., 2015, Henjakovic et al., 2015), this may not be the case for glutarate, for which an efflux transporter is not known. 
Table 2 summarizes our findings and compares them with published results on MRP4. Dantrolene, glafenine, nalidixic acid, and prazosin inhibited OAT3 as well as MRP4, indicating overlapping inhibitor specificities. Dantrolene had a more than 10-fold higher affinity, and nalidixic acid and prazosin a 2- to 3-fold lower affinity for OAT3 than for MRP4. With the exception of prazosin, the maximum plasma concentrations are either in the range (glafenine) or above (dantrolene, nalidixic acid) the $\mathrm{IC}_{50}$ values. All four drugs shifted the equilibrium distribution of ES, suggesting that OAT3 may take up dantrolene, glafenine, nalidixic acid, and prazosin across the basolateral membrane and MRP4 may efflux these compounds into the urine. A finite proof of translocation of these drugs by OAT3 and MRP4, however, awaits further experimentation. The $\mathrm{IC}_{50}$ values obtained with glutarate as a reference substrate for OAT1 were higher than (dantrolene, glafenine, prazosin) or in the range of (nalidixic acid) those obtained with MRP4. Thus, although there is some overlapping specificity, OAT1 may in vivo play a role, if at all, only in the transport of nalidixic acid.

\section{Acknowledgments}

The authors wish to thank Andrea Paluschkiwitz and Sören Petzke for skillful technical assistance.

\section{Authorship Contributions}

Participated in research design: B.C. Burckhardt, G. Burckhardt, Hagos, Henjakovic.

Conducted experiments: B.C. Burckhardt, Henjakovic.

Performed data analysis: B.C. Burckhardt.

Wrote or contributed to the writing of the manuscript: B.C. Burckhardt, G. Burckhardt.

\section{References}

Batty M, Pugh R, Rathinam I, Simmonds J, Walker E, Forbes A, Anoopkumar-Dukie S, McDermott CM, Spencer B, Christie D, et al. (2016) The role of $\alpha 1$-adrenoceptor antagonists in the treatment of prostate and other cancers. Int J Mol Sci 17:E1339.

Belzer M, Morales M, Jagadish B, Mash EA, Wright SH (2013) Substrate-dependent ligand inhibition of the human organic cation transporter OCT2. J Pharmacol Exp Ther 346:300-310.

Bradford MM (1976) A rapid and sensitive method for the quantitation of microgram quantities of protein utilizing the principle of protein-dye binding. Anal Biochem 72:248-254.

Burckhardt G (2012) Drug transport by organic anion transporters (OATs). Pharmacol Ther 136:106-130.

Cheung L, Yu DMT, Neiron Z, Failes TW, Arndt GM, and Fletcher JI (2015) Identification of new MRP4 inhibitors from a library of FDA approved drugs using a high-throughput bioluminescence screen. Biochem Pharmacol 93:380-388.

Dantzler WH (2002) Renal organic anion transport: a comparative and cellular perspective. Biochim Biophys Acta 1566:169-181.

Digne-Malcolm H, Frise MC, and Dorrington KL (2016) How do antihypertensive drugs work? Insights from studies of the renal regulation of arterial blood pressure. Front Physiol 7:320.

Egenberger B, Gorboulev V, Keller T, Gorbunov D, Gottlieb N, Geiger D, Mueller TD, and Koepsell H (2012) A substrate binding hinge domain is critical for transportrelated structural changes of organic cation transporter 1. J Biol Chem 287: 31561-31573.

Fàbrega A, Madurga S, Giralt E, and Vila J (2009) Mechanism of action of and resistance to quinolones. Microb Biotechnol 2:40-61.

Guelen PJM, Janssen TJ, Lam MH, Vree TB, and Exler PS (1990) Comparative bioavailability study of two brands of prazosin-containing tablets in healthy volunteers. Pharm Weekbl Sci 12:184-187.
Harper JN and Wright SH (2013) Multiple mechanisms of ligand interaction with the human organic cation transporter, OCT2. Am J Physiol Renal Physiol 304: F56-F67.

Henjakovic M, Hagos Y, Krick W, Burckhardt G, and Burckhardt BC (2015) Human organic anion transporter 2 is distinct from organic anion transporters 1 and 3 with respect to transport function. Am J Physiol Renal Physiol 309:F843-F851.

Hiraoka Y, Taniguchi T, Tanaka T, Okada K, Kanamaru H, and Muramatsu I (2003) Pharmacological characterization of unique prazosin-binding sites in human kidney. Naunyn Schmiedebergs Arch Pharmacol 368:49-56.

Hotchkiss AG, Gao T, Khan U, Berrigan L, Li M, Ingraham L, and Pelis RM (2015) Organic anion transporter 1 is inhibited by multiple mechanisms and shows a transport mode independent of exchange. Drug Metab Dispos 43:1847-1854.

Ingraham L, Li M, Renfro L, Parker S, Vapurcuyan A, Hanna I, and Pelis RM (2014) A plasma concentration of $\alpha$-ketoglutarate influences the kinetic interaction of ligands with organic anion transporter 1. Mol Pharmacol 86:86-95.

Jaillon P (1980) Clinical pharmacokinetics of prazosin. Clin Pharmacokinet 5: 365-376.

Kaufhold M, Schulz K, Breljak D, Gupta S, Henjakovic M, Krick W, Hagos Y, Sabolic I, Burckhardt BC, and Burckhardt G (2011) Differential interaction of dicarboxylates with human sodium-dicarboxylate cotransporter 3 and organic anion transporters 1 and 3. Am J Physiol Renal Physiol 301:F1026-F1034.

Keppler D (2011) Multidrug resistance proteins (MRPs, ABCCs): importance for pathophysiology and drug therapy, in Drug Transporters Handb Exp Pharmacol (Fromm MF and Kim RB eds) pp 299-323, Springer, Heidelberg, Dodrecht, London, New York

Krause T, Gerbershagen MU, Fiege M, Weisshorn R, and Wappler F (2004) Dantrolenea review of its pharmacology, therapeutic use and new developments. Anaesthesia 59:364-373.

Masereeuw R and Russel FGM (2010) Therapeutic implications of renal anionic drug transporters. Pharmacol Ther 126:200-216.

Morrissey KM, Stocker SL, Wittwer MB, Xu L, and Giacomini KM (2013) Renal transporters in drug development. Annu Rev Pharmacol Toxicol 53:503-529.

Nigam SK, Bush KT, Martovetsky G, Ahn S-Y, Liu HC, Richard E, Bhatnagar V, and $\mathrm{Wu} \mathrm{W}$ (2015) The organic anion transporter (OAT) family: a systems biology perspective. Physiol Rev 95:83-123.

Pelis RM and Wright SH (2011) Renal transport of organic anions and cations. Compr Physiol 1:1795-1835.

Reid G, Wielinga P, Zelcer N, De Haas M, Van Deemter L, Wijnholds J, Balzarini J, and Borst P (2003) Characterization of the transport of nucleoside analog drugs by the human multidrug resistance proteins MRP4 and MRP5. Mol Pharmacol 63: 1094-1103.

Rosenberg H, Pollock N, Schiemann A, Bulger T, and Stowell K (2015) Malignant hyperthermia: a review. Orphanet $J$ Rare Dis 10:93.

Roth M, Timmermann BN, and Hagenbuch B (2011) Interactions of green tea catechins with organic anion-transporting polypeptides. Drug Metab Dispos 39 920-926.

Russel FG, Koenderink JB, and Masereeuw R (2008) Multidrug resistance protein 4 (MRP4/ABCC4): a versatile efflux transporter for drugs and signalling molecules. Trends Pharmacol Sci 29:200-207.

Smeets PHE, van Aubel RAMH, Wouterse AC, van den Heuvel JJMW, and Russel FGM (2004) Contribution of multidrug resistance protein 2 (MRP2/ABCC2) to the renal excretion of $p$-aminohippurate $(\mathrm{PAH})$ and identification of MRP4 (ABCC4) as a novel PAH transporter. J Am Soc Nephrol 15:2828-2835.

Tahara H, Kusuhara H, Endou H, Koepsell H, Imaoka T, Fuse E, and Sugiyama Y (2005) A species difference in the transport activities of $\mathrm{H}_{2}$ receptor antagonists by rat and human renal organic anion and cation transporters. J Pharmacol Exp Ther 315:337-345.

VanWert AL, Gionfriddo MR, and Sweet DH (2010) Organic anion transporters: discovery, pharmacology, regulation and roles in pathophysiology. Biopharm Drug Dispos 31:1-71.

Vermerie N, Kusielewicz D, Tod M, Nicolas P, Perret G, Fauvelle F, and Petitjean O (1992) Pharmacokinetics of glafenine and glafenic acid in patients with cirrhosis, compared to healthy volunteers. Fundam Clin Pharmacol 6:197-203.

Wen J, Luo J, Huang W, Tang J, Zhou H, Zhang W (2015) The pharmacological and physiological role of multidrug-resistance protein 4. J Pharmacol Exp Ther 354: 358-375.

Withdrawal of glafenine (1992) Lancet 339:357.

Address correspondence to: Dr. Birgitta C. Burckhardt, Center of Physiology and Pathophysiology, University Medical Center Goettingen, Humboldtallee 23, 37073 Goettingen, Germany. E-mail: birgitta.burckhardt@ med.uni-goettingen.de 